Abstracta Iranica Abstracta Iranica

Revue bibliographique pour le domaine irano-aryen

Volume 23 | 2002

Comptes rendus des publications de $\mathbf{2 0 0 0}$

\title{
«Boire à la coupe de la vie ou : la Coupe de Djamshîd ». Kârnâmeh, 6, (2000), pp. 51-66.
}

\section{Rédaction}

\section{OpenEdition}

1 Journals

\section{Édition électronique}

URL : http://journals.openedition.org/abstractairanica/35799

DOI : 10.4000/abstractairanica.35799

ISSN : 1961-960X

Éditeur :

CNRS (UMR 7528 Mondes iraniens et indiens), Éditions de l'IFRI

\section{Édition imprimée}

Date de publication : 15 mai 2002

ISSN : 0240-8910

\section{Référence électronique}

Rédaction, « "Boire à la coupe de la vie ou : la Coupe de Djamshîd ». Kârnâmeh, 6, (2000), pp. 51-66. », Abstracta Iranica [En ligne], Volume 23 | 2002, document 265, mis en ligne le 08 février 2010, consulté le 25 septembre 2020. URL : http://journals.openedition.org/abstractairanica/35799 ; DOI : https:// doi.org/10.4000/abstractairanica.35799

Ce document a été généré automatiquement le 25 septembre 2020.

Tous droits réservés 
«Boire à la coupe de la vie ou : la Coupe de Djamshîd ». Kârnâmeh, 6, (2000), pp. 51-66.

Rédaction

1 C.r. à paraître dans le prochain numéro d'Abs. Ir.

\section{INDEX}

Thèmes : 11.1.1. Littérature persane classique

\section{AUTEURS}

RÉDACTION

Directeur de la revue et secrétariats (Paris et Téhéran) 